\title{
Occurrence of gastrointestinal parasites in Spheniscus magellanicus (Foster, 1781) located in Pontal do Sul, PR, Brazil
}

\author{
[Ocorrência de parasitas gastrintestinais em Spheniscus magellanicus (Foster, 1781)
} localizados em Pontal do Sul, PR, Brasil]

\author{
M.S. Vanhoni ${ }^{1,2}$, G.M. Arná ${ }^{1,2}$, L.K. Sprenger ${ }^{4}$, D.L. Vieira ${ }^{1,3}$, L.W. Luis ${ }^{1,2}$, M.B. Molento ${ }^{1,5 *}$ \\ ${ }^{1}$ Universidade Federal do Paraná - Curitiba, PR \\ ${ }^{2}$ Aluno(a) de graduação- Universidade Federal do Paraná - Curitiba, PR \\ ${ }^{3}$ Aluno(a) de pós-graduação - Universidade Federal do Paraná - Curitiba, PR \\ ${ }^{4}$ Faculdades Integradas do Vale do Iguaçu - União da Vitória, PR \\ ${ }^{5}$ Instituto Nacional de Ciência e Tecnologia - Belo Horizonte, MG
}

\begin{abstract}
Gastrointestinal parasitism is the main health problem faced by Spheniscus magellanicus, known as Magellanic penguins, in route on the Brazilian coast. The aim of this research was to report the occurrence and intensity of gastrointestinal parasites in S. magellanicus that reached Pontal do Sul, Paraná, South of Brazil. The study was performed at the Marine Study Center of the Federal University of Parana (CEM-UFPR) with 38 specimens, 31 were necropsied and seven were examined alive with coproparasitological exams. From the necropsied animals, 93.5\% (29/31) were parasitized with at least one parasite species. Contracaecum pelagicum was the most prevalent 93,5\% (29/31) parasite, followed by Cardiocephaloides physalis (64.5\%) and Tetrabothrius lutzi (51.6\%). Only one animal was free of parasites and the most infected bird had 1.076 parasites with an average of 194 worms. Willis-Mollay method revealed that $57.1 \%$ (4/7) had C. pelagicum eggs. In conclusion, the high rate of gastrointestinal parasites in S. magellanicus confirms the clinical exams, when animals had poor health conditions when they were found in the cost of Paraná. This study provides data to enrich the literature regarding the helminth fauna of the Magellanic penguins, assisting sanitary control programs in Rehabilitation Centers for Marine Animals.
\end{abstract}

Keywords: endoparasites, parasitic diseases, wild birds

\section{RESUMO}

As parasitoses gastrintestinais são o principal problema sanitário enfrentado pelo Spheniscus magellanicus, conhecido como pinguim-de-magalhães, que faz rota no litoral brasileiro. O objetivo desta pesquisa foi relatar a ocorrência e a intensidade de parasitas gastrintestinais em Spheniscus magellanicus encontrados em Pontal do Sul, Paraná, Sul do Brasil. O estudo foi realizado no Centro de Estudos Marinhos da Universidade Federal do Paraná, CEM-UFPR, com 38 espécimes; 31 dos quais foram necropsiados, e em sete aves vivas foram realizados exames coproparasitológicos. Do total analisado, 93,5\% (29/31) aves estavam parasitadas com pelo menos uma espécie, sendo o Contracaecum pelagicum o mais prevalente, 93,5\% (29/31), seguido de Cardiocephaloides physalis $(64,5 \%)$ e de Tetrabothrius lutzi $(51,6 \%)$. Somente um animal estava livre de parasitas e a ave mais infectada possuía 1.076 parasitas; a média foi em 194 vermes. No exame de Willis-Mollay, foi observada positividade em $57,1 \%$ (4/7) para C. pelagicum. Conclui-se que o alto índice de parasitas gastrintestinais em S. magellanicus confirma os exames clínicos que eles apresentaram, de baixa condição sanitária, quando foram encontrados no litoral do Paraná. Este estudo fornece dados que irão enriquecer a literatura sobre a helminto fauna do pinguim-de-magalhães, auxiliando programas de controle sanitário em Centros de Reabilitação de Animais Marinhos.

Palavras-chave: endoparasitas, aves selvagens, doenças parasitárias

Recebido em 30 de agosto de 2016

Aceito em 3 fevereiro de 2017

*Autor para correspondência (corresponding author)

E-mail: molento@ufpr.br 


\section{INTRODUCTION}

Among the 18 penguins species recorded, Spheniscus magellanicus Foster, 1781 (Sphenisciformes: Sphenisidae), known as the Magellanic penguin, is the most commonly found in temperate areas. This species has an estimated population of 1.3 million breeding pairs (Silva-Barreto et al., 2015) mainly in the Falkland Islands and in the Argentinian Patagonia. It is also the most frequent species found in the Brazilian coast during seasonal periods. These birds eat mainly small fish (i.e. anchiotas) but they can also feed on squids and small crustaceans (Ederli et al., 2009). The life cycle of Magellanic penguin is defined, since near three months age the young penguins are separated from their parents and start the marine life, pursuing their food supply. In this period, they perform the winter migration (May to July) returning to their home colonies in Chile, Argentina and the Falkland Islands in August to September (Hippólito et al., 2012).

Although there is no real estimate of the number of these birds, several penguins regularly reach the Southern and Southeastern Brazilian coast by the end of the winter during migratory process. The animals are mostly young penguins that move away from their group and arrive debilitated or dead (Garcia-Borboroglu et al., 2010). Numerous factors play an important role in weakening the Magellanic penguins during migration, such as non-infectious diseases, oil contamination (or other pollutants), gastrointestinal parasites, accidents with fish nets, traumas, or foreign-body ingestion (Fonseca et al., 2001; Mäder et al., 2010).

Gastrointestinal parasites are a sanitary problem in penguins, affecting their behavior, productivity, reproduction and also population growth (Fonseca et al., 2001; Mäder et al., 2010). In a study performed in the state of Rio de Janeiro, $100 \%$ of the animals showed a high prevalence of gastrointestinal helminths (Campos et al., 2013), particularly Contracaecum pelagicum (Johnston \& Mawson 1942) (Nematoda: Anisakidae), Cardiocephaloides physalis (Lutz, 1927) (Trematoda: Strigeidae) and Tetrabothrius lutzi (Parona, 1901) (Cestoda: Tetrabothriidae). These parasites were also the most frequent in the North Coast of the state of São Paulo, when $49.8 \%$ of the animals carried at least one of the above species (Rezende et al., 2013).

Parasites of the genus Contracaecum (Railliet; Henry, 1912) have several fish species as intermediate hosts and fish-eating birds and marine mammals are their definitive host (Anderson, 2000). The digenetic trematode genus Cardiocephaloides (Sudarikov, 1959) is the second most frequent parasite in $S$. magellanicus (Mäder et al., 2010). Even though least common, T. lutzi may be the potential cause of death to $S$. magellanicus. This species was reported in $85.6 \%$ of the animals in a study performed by González-Acuña et al. (2008) in Chile.

While the Magellanic penguin is the most abundant species in Temperate regions the two largest breeding colonies of Argentina have experienced a significant decline in the last years (Petry et al., 2011). There are still very few data on the number of Magellanic penguins that die each year on the Brazilian coast and on the cause of their mortality. In Rio Grande do Sul, the most Southern state of Brazil, it is known that nearly 19.500 carcasses appear on the coast every year, where $97 \%$ are from young penguins. As the population is noticeably declining, the Magellanic Penguin is, nowadays, classified as a 'near threatened' species by the International Union for Conservation of Nature, increasing the necessity to gather more information to support actions aimed at their protection and conservation (Hippólito et al., 2012).

The objective of this study was to determine the occurrence of gastrointestinal parasites in $S$. magellanicus that reached the coastal area of Pontal do Sul, PR, South of Brazil. This data may become an important source of information about parasite infection in Magellanic penguins, improving the knowledge on their health condition assisting rehabilitation Centers for Marine Animals.

\section{MATERIAL AND METHODS}

The study was performed at the Marine Study Center of the Federal University of Parana, CEM/UFPR with 38 S. magellanicus found from August 2014 to July 2015 in the coastal area of

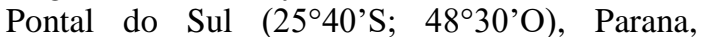
Brazil. During this period, 31 necropsies were 
conducted by the CEM responsible personnel in animals that died for any reason. The carcasses were stored at $-20^{\circ} \mathrm{C}$, and after necropsy, the organs from the gastrointestinal tract were removed, individually identified, and sent to the Parasitic Diseases Laboratory, UFPR (252 $5^{\prime} \mathrm{S}$, $\left.49^{\circ} 16^{\prime} \mathrm{O}\right)$ for parasite morphological identification according to Diaz et al. (2010). The intestine, stomach and esophagus were separated, and the samples were cleaned in distilled water. After the intestinal lumen was exposed, the entire content was removed and passed through a $250 \mathrm{~mm}$ mesh to retain adult parasites. The content retained in the sieve was deposited in Petri dishes and the parasites were microscopically separated for manual counting. The parasites were analyzed under stereo microscope (Zeiss Stemi 2000, Switzerland).
Faecal material was collected from seven animals at the rehabilitation area. The faeces were collected with latex gloves from a clean floor, individually stored in plastic bags and kept under refrigeration $\left(4^{\circ} \mathrm{C}\right)$. The coproparasitological evaluation was performed through Willis-Mollay method (1921) and the slides were observed at 10x objective (Olympus CX-40, USA).

\section{RESULTS}

Among the 31 necropsied samples of $S$. magellanicus, 29 (93,5\%) were heavily infected with at least one parasite species. The helminth fauna included the nematode $C$. pelagicum, the digenetic $C a$. physalis and the cestode $T$. lutzi. The results regarding the occurrence and co-infection of the parasites are reported in Table 1. The results concerning the numbers of the parasites are reported in Table 2.

Table 1. Occurrence (\%) and co-infection of Contracaecum pelagicum, Cardiocephaloides physalis and Tetrabothrius lutzi identified in the gastrointestinal tract of Spheniscus magellanicus (Magellanic Penguin) from the Marine Study Center, UFPR, Pontal do Sul, Brazil

\begin{tabular}{lccc}
\hline \multicolumn{1}{c}{ Species } & Phylum & Site & Occurrence $(\%)$ \\
\hline Contracaecum pelagicum & Nematoda & 1,2 & 93,5 \\
Cardiocephaloides physalis & Platyhelminthes & 3 & 64,5 \\
Tetrabothrius lutzi & Platyhelminthes & 3 & 51,6 \\
C. pelagicum and Ca. physalis & Nematoda/Platyhelminthes & $1,2,3$ & 64,5 \\
C. pelagicum and T. lutzi & Nematoda/Platyhelminthes & $1,2,3$ & 48,4 \\
Ca. physalis and T. lutzi & Platyhelminthes & 3 & 41,9 \\
All species & Nematoda/Platyhelminthes & $1,2,3$ & 41,9 \\
\hline
\end{tabular}

C. pelagicum: Contracaecum pelagicum; Ca. physalis: Cardiocephaloides physalis; T. lutzi: Tetrabothrius lutzi; Site of parasitism: 1. Stomach, 2. Esophagus, 3. Small Intestine.

Only one animal was free of parasites and the most infected bird had over 1.100 parasites. The animals had an average of 194 worms (standard deviation of 213). It was not possible to quantify $T$. lutzi due to their very delicate morphology and its excessive numbers. Although the T. lutzi was recurrently obtained entangled in $50.7 \%$ of the animals, their separation and manual counting was hindered.

Table 3 describes the helminth egg counts from the rehabilitation area, where $57.1 \%(4 / 7)$ had $C$. pelagicum eggs, from as high as 150 eggs. There were no $\mathrm{Ca}$. physalis and T. lutzi eggs.

\section{DISCUSSION}

The results observed in this study showed for the first time that most birds were heavily parasitized with infections ranging from 25 to 1076. The most prevalent species were $C$. pelagicum (93.5\%), followed by $\mathrm{Ca}$. physalis $(64.5 \%)$ and T. lutzi (51.6\%). These parasites were also reported in Argentina (T. lutzi 85\%; C. pelagicum 67\%; Ca. physalis 56\%) (Diaz et al., 2010), Chile (T. lutzi 8,3\%; C. pelagicum 33\%; Ca. physalis 16,7\%) (González-Acuña et al., 2008) and the North coast of São Paulo, Brazil (T. lutzi 26,6\%; C. pelagicum 49,4\%; Ca. physalis 22,4\%) (Rezende et al., 2013) but these studies did not proceed with parasite counts. 
Table 2. Quantification of Contracaecum pelagicum, Cardiocephaloides physalis and Tetrabothrius lutzi identified in the gastrointestinal tract of Spheniscus magellanicus (Magellanic Penguin) from the Marine Study Center, UFPR, Pontal do Sul, PR, Brazil

\begin{tabular}{|c|c|c|c|}
\hline Species/ $\mathrm{N}^{\mathrm{O}}$ & $\begin{array}{c}\text { Contracaecum } \\
\text { pelagicum }\end{array}$ & Cardiocephaloides physalis & Tetrabothrius lutzi * \\
\hline 1 & 138 & 30 & + \\
\hline 2 & 08 & 38 & + \\
\hline 3 & 380 & Negative & Negative \\
\hline 4 & 100 & 42 & + \\
\hline 5 & 127 & Negative & Negative \\
\hline 6 & 06 & Negative & + \\
\hline 7 & 36 & 33 & Negative \\
\hline 8 & 02 & Negative & Negative \\
\hline 9 & 754 & 91 & ++ \\
\hline 10 & 40 & 08 & Negative \\
\hline 11 & 148 & 23 & Negative \\
\hline 12 & 160 & 90 & + \\
\hline 13 & 37 & 93 & + \\
\hline 14 & 03 & Negative & Negative \\
\hline 15 & 22 & 03 & Negative \\
\hline 16 & 63 & 43 & + \\
\hline 17 & 303 & 63 & Negative \\
\hline 18 & Negative & Negative & Negative \\
\hline 19 & 06 & Negative & Negative \\
\hline 20 & 170 & 44 & + \\
\hline 21 & 13 & 34 & Negative \\
\hline 22 & 37 & Negative & + \\
\hline 23 & 950 & 126 & ++ \\
\hline 24 & 150 & 48 & + \\
\hline 25 & 58 & Negative & Negative \\
\hline 26 & 174 & 128 & + \\
\hline 27 & 06 & 34 & + \\
\hline 28 & Negative & Negative & + \\
\hline 29 & 68 & Negative & Negative \\
\hline 30 & 138 & 30 & + \\
\hline 31 & 35 & 30 & Negative \\
\hline
\end{tabular}

* As the parasite count was difficult, the parasite intensity was established as: (+) one to five parasites; $(++)$ six to twenty parasites; $(+++)$ more than twenty-one parasites.

Table 3. Frequency of Contracaecum pelagicum, Cardiocephaloides physalis and Tetrabothrius lutzi eggs in Spheniscus magellanicus (Magellanic Penguin) from the Marine Study Center, UFPR, Pontal do Sul, PR, Brazil

\begin{tabular}{cccc}
\hline $\mathrm{N}^{\mathrm{O}}$ & Contracaecum pelagicum & Cardiocephaloides physalis & Tetrabothrius lutzi \\
\hline 01 & Negative & Negative & Negative \\
02 & Negative & Negative & Negative \\
03 & Negative & Negative & Negative \\
04 & $<50(++++)$ & Negative & Negative \\
05 & $1-10(+)$ & Negative & Negative \\
06 & $<150(+++++)$ & Negative & Negative \\
07 & $1-10(+)$ & Negative & Negative \\
\hline
\end{tabular}

As the parasite count was difficult, the parasite intensity established as: (+) one to five parasites; (++) six to twenty parasites; $(+++)$ more than twenty-one parasites; $(++++)$ more than fifty one; $(++++)$ more than on hundred and fifty one. 
As identified by their fluff type, all animals involved in this study were young with less than one year of age. In the wild, apart from being sick, young animals may be less experienced, and could more easily lose themselves from the flock and find difficulties to search for food (Prado et al., 2011). This finding correlates well to the poor body conditions they were observed at arrival. Mäder et al. (2010) reported that this weakness combined with the stress from the lack of food and contact with other penguins may have a negative influence on their immune system, predisposing the birds to parasite infections. Although we did not investigate this factor, it may have also been the main cause of the observed high death rate. The gastrointestinal parasites can also contribute to the animal's death, since physically debilitated animals are the main feature on strand animals on the Brazilian coast (Mäder et al., 2010).

The prevalence of $C$. pelagicum in these birds was demonstrated by Garbin et al. (2013) who performed a necropsy study to determinate the helminth fauna from Magellanic penguins in the Southeastern coast of Argentina. The low prevalence of $C a$. physalis when compared to $C$. pelagicum can be explained by its biological cycle as they use the anchiota fish (Engraulis anchoita) as intermediate host (Ederli et al., 2009). The young Magellanic penguins found early in the winter on the Brazilian Southern coast are from Patagonia, during their first migration (Barros et al., 2009). At this time, the prevalence of anchiota is low, as this fish is more common in the North coast of Brazil. Therefore, the exposition of the birds to Ca. physalis metacercariae was considerably low (Rezende $e t$ al., 2013). However, C. pelagicum has many fish species as intermediary or paratenic hosts and also has many fishing birds and mammals as definitive hosts (Anderson, 2000) causing a greater prevalence of infection. The intrinsic life cycle associated with the restricted eating habits of the Magellanic penguins could be the cause of the low helminth variety found in the animals.

T. lutzi is regularly found in seabirds that inhabit the Antarctic and Southern region of South
America, being described in Chile (GonzálezAcuña et al., 2009), Argentina (Pazos et al., 2003) and Brazil (Rezende et al., 2013). In spite of having a great diversity of marine birds from Antarctic as definitive host, the parasite has few intermediary and paratenic hosts. This fact, combined to the restrict habitat of the definitive hosts might be the main aggravating factors of the low prevalence of $T$. lutzi also observed in other studies (González-Acuña et al., 2009; Mäder et al., 2010; Rezende et al., 2013). Diaz et al. (2010) working in the Valdez Peninsula, Argentina, found T. lutzi as the most prevalent helminth, probably as a result of the geographic distribution of its intermediary hosts, which are normally present in this region (Borges et al., 2014). In our study, we were surprise by the enormous numbers of this parasite infecting most of the animals.

There are no records of studies with coproparasitological diagnostic in living penguins, or quantification of the gastrointestinal parasites. The data extracted from this research will help other institutions with similar rehabilitation centers of marine animals to establish a more appropriate parasite/sanitary control protocols, improving animal welfare. Considering the birds' difficulties of spontaneous recovery and return to their habitat when they arrive on the Brazilian Coast, the veterinary treatment becomes an important tool for rehabilitation and reintroduction of penguins back in nature.

\section{CONCLUSION}

The high prevalence of the three parasites in this study shows that gastrointestinal parasites are one of the major sanitary problems in penguins found in the Brazilian coast.

\section{ACKNOWLEDGMENTS}

The authors wish to thank Dr. Débora Cristina Pelim Lima from the CEM-UFPR for her technical assistance and suggestions on the present work. 


\section{REFERENCES}

ANDERSON, R.C. Nematode parasites of vertebrates: their development and transmission. New York: Cabi Publishing, 2000. 650p.

BARROS, H.M.; GUIMARÃES, R.R.; COSTALIMA, A. Averiguação da presença de ectoparasitas no pinguim Spheniscus magellanicus capturado em Arraial do Cabo. Cienc. Tecnol., v.9, p.24, 2009.

BORGES, J.N.; SANTOS, H.L.C.; BRANDÃO, M.L. et al. Molecular and morphological characterization of Contracaecum pelagicum (Nematoda) parasitizing Spheniscus magellanicus (Chordata) from Brazilian waters. Rev. Bras. Parasitol. Vet., v.23, p.74-79, 2014.

CAMPOS, S.D.; PEREIRA, B.B.N.; SICILIANO, S. et al. Contracaecum pelagicum and $C$. plagiaticium (Nematoda: Anisakidae) infection in Magellanic penguins (Sphenisciformes: Spheniscidae) on the coast of Rio de Janeiro State. Pesqui. Vet. Bras., v.33, p.8993, 2013.

DIAZ, J.I.; CREMONTE, F.; NAVONE, G.T. Helminths of the Magellanic penguin, Spheniscus magellanicus (Sphenisciformes), during the breeding season in Patagonian coast, Chubut, Argentina. Comp. Parasitol., v.77, p.172-177, 2010.

EDERLI, N.B.; OLIVEIRA, F.C.R.; MONTEIRO, C.M. et al. Occurrence of Contracaecum pelagicum Johnston \& Mawson, 1942 (Nematoda, Anisakidae) in Magellanic penguin (Spheniscus magellanicus Forster, 1781) (Aves, Spheniscidae) at Espírito Santo coast. Arq. Bras. Med. Vet. Zootec., v.61, p.1006-1008, 2009.

FONSECA, V.S.S.; PETRY, M.V.; JOST, A.H. Diet of the Magellanic penguin on the coast of Rio Grande do Sul, Brazil. Waterbirds, v.24, p.290-293, 2001.

GARBIN, L.E.; MATTIUCCI, S.; PAOLETTI M. et al. Molecular identification and larval morphological description of Contracaecum pelagicum (Nematoda: Anisakidae) from the anchovy Engraulis anchoita (Engraulidae) and fish-eating birds from the Argentine North Patagonian Sea. Parasitol. Int., v.62, p.309-319, 2013.

GARCÍA-BORBOROGLU, P.; BOERSMA， P.D.; RUOPPOLO, V. et al. Magellanic penguin mortality in 2008 along the SW Atlantic coast. Marine Poll. Bull., v.60, p.1652-1657, 2010.
GONZÁLEZ-ACUÑA, D.; KINSELLA, J.M.; LARA, J.; VALENZUELA-DELLAROSSA, G. Parásitos gastrointestinales en pingüino de Humboldt (Spheniscus humboldti) y pingüino de Magallanes (Spheniscus magellanicus) en las costas del centro y centro sur de Chile. Parasitol. Latinoam., v.63, p.5863, 2008.

HIPPÓLITO, A.G.; BERTOLI, R.S.; LANGE, R.R. et $a l$. Alteração hematológica e bioquímica em pinguinsdemagalhães (Spheniscus magellanicus) tratados com itraconazol por um mês. Rev. Educ. Cont. Med. Vet. Zootec., v.10, p.43-44, 2012.

MÄDER, A.; SANDER, M.; CASA JÚNIOR, G. Ciclo sazonal de mortalidade do pinguim-deMagalhães, Spheniscus magellanicus influenciado por fatores antrópicos e climáticos na costa do Rio Grande do Sul, Brasil. Rev. Bras. Ornitol., v.18, p.228-233, 2010.

PAZOS, G.E.; LAURENTI, S.; DÍAZ, J.I. Helmintofauna del pinguino de Magallanes (Spheniscus magellanicus) em península Valdes, província del Chubut. Resultados preliminares. Hist. Nat., v.2, p.85-94, 2003.

PETRY, M.V.; SCHERER, J.D.F.M.; SCHERER, A.L. Ocorrência, alimentação e impactos antrópicos de aves marinhas nas praias do litoral do Rio Grande do Sul, sul do Brasil. Rev. Bras. Ornitol., v.20, p.65-70, 2011.

PRADO, M.I.B.M.; SANTOS-LÓPES, A.R.; SILVA, R.J. Helminthfauna of Magellanic penguin (Spheniscus magellanicus Foster, 1781) proceeding from Ilha Comprida, South Coast, State of São Paulo, Brazil. Neotrop. Helminthol., v.5, p.50-55, 2011.

REZENDE, G.C.; BALDASSIN, P.; GALLO, H.; SILVA, R.J. Ecological aspects of helminth fauna of Magellanic penguins, Spheniscus magellanicus (aves: Spheniscidae), from the Northern Coast of the State of São Paulo, Brazil. Braz. J. Biol., v.73, p.61-66, 2013.

SILVA-BARRETO, J.; FREITAS, T.R.O.; FERNÁNDEZ, G.P. Razão sexual assimétrica entre carcaças de Spheniscus magellanicus na costa norte do Rio Grande do Sul. Ornithologia, v.8, p.75-77, 2015.

SPHENISCUS magellanicus. IUCN Red List Threatened Species, 13p, 2012. (E.T. 22697822A37820611). 